\section{The suspense of strangeness}

\author{
Science supplies poetry with a register \\ of words outside common usage.
}

\section{Maurice Riordan}

$\mathrm{T}$ here is a line about moonlight by Sylvia Plath that I find haunting: "This is the light of the mind, cold and planetary." My ear is arrested by the rhythm - by the way the line runs quickly into the strong stress on "mind", which then collides immediately with the stress on "cold" before the line spins off into space. Except the space created by the metaphor is inner space, so that there is also a collision of inner and outer worlds. The effect is disturbing, is meant to be disturbing: the imagining mind is breached, cleaned out and (for a moment) exhilarated by the hostile image of nature.

The line is scientific, of course, only in the flimsiest sense. Even so, to the degree that it is, it is crucial to the effect: "light" generally brings associations of illumination, vision, transcendence. But not here: the use of "planetary" erases these associations and replaces them with physical, actual light.

This illustrates something about how poets use words with scientific associations. They exist in a state of sensitive relationship with everything else in a poem - and on an equal basis, which means they have to work: they must earn their keep by at least increasing the surface tension of the language. They are, then, part of the poem's imaginative exertion, that promiscuous agility of language which, as described by the nineteenth-century Italian poet Giacomo Leopardi, "keeps the mind in constant and lively movement and action, transporting it suddenly, and often abruptly, from one thought, image, idea, or object to another, and often to one very remote and different; so that the mind must work to overtake them all, and, as it is flung here and there, feels invigorated".

One very remote and different: Leopardi's phrase suggests the particular lure science has for poets. Science supplies a register of words outside common usage; it provides a stock of ideas often far removed from our everyday observation of things; and this body of knowledge seems to be an objective description of the world. Thus, science has the potential to give a poem what the American poet Elizabeth Bishop called "the suspense of strangeness", a sense of being in a world that is at once engrossing and unpredictable.

This rules out attempts to write earnest, educative poems about science. Scientists are sometimes puzzled by this. Why doesn't a scientific sense of wonder translate readily into poetry? To give an adequate answer might require looking back to classical poetry, when a religious and transcendent view of nature dominated the imagination. But my aim is more reachable: to cite some well-known English poems that seem to me to exemplify how poets can engage imaginatively with words and ideas that derive necessarily from a materialist model of the world.

This is John Donne, whose life coincided with the beginnings of modern science and whose great theme is the body spiritualized and eroticized by love, writing just when William Harvey was pioneering anatomical research:

Know'st thou but how the stone

dothenter in

The bladder's cave and never break the skin?

Know'st thou how blood, which to the heart doth flow,

Doth from one ventricle to th'other go?

And for the putrid stuff which thou

dost spit,

Knows't thou how thylungs

have attracted it?

Never mind that Donne opposes scientific enquiry of any kind. This does not limit the daring of the lines. They imagine - for the first time, I think, in English poetry — the body as a biological entity. They take us from the outside to the inside, visualizing the body in familiar physical images but also using technical terms. This elasticity creates a tension between the personal and the impersonal, the body as 'thou' and the body as object. In fact, the whole passage, some 40 lines from 'The Second Anniversary', conveys both a religious despair at human ignorance and a transgressive curiosity about our physical nature.

Science is an unfolding narrative, one that answered Donne's questions only to raise a good many more. It posits the world as discoverable, perhaps indefinitely so. But it also reveals nature as different. It produces a version of reality at odds with orthodox thinking, and one that in any case is often beyond human measure in its scale and complexity. Few great poems in English open their doors to this northern wind, and when they do they are hinged with reluctance. Alfred, Lord Tennyson, like most nineteenth-century poets, was appalled by the

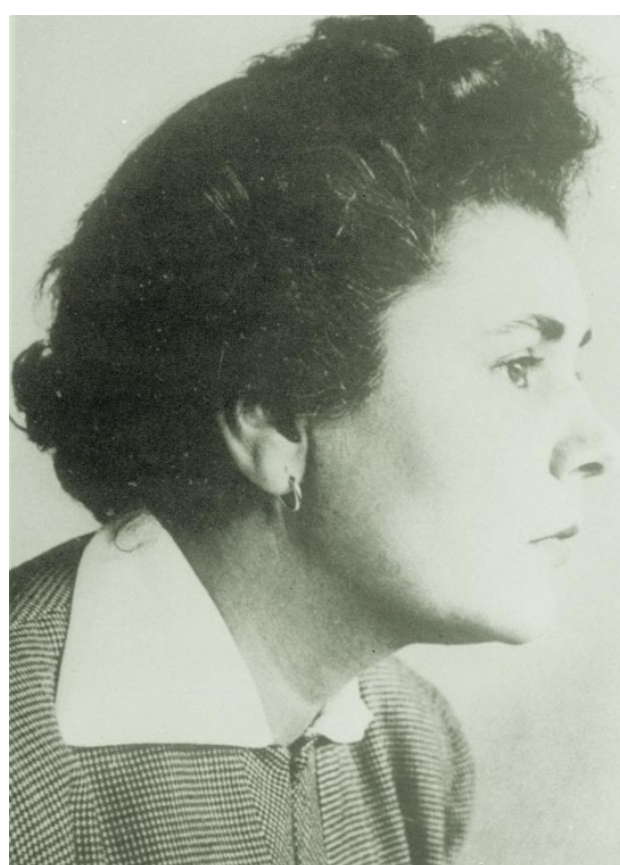

Poet Elizabeth Bishop believed some words could create a world at once engrossing and unpredictable.

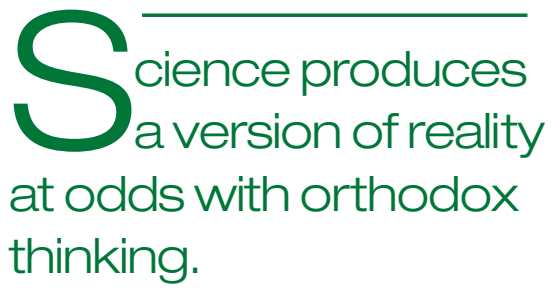

mechanistic implications of contemporary science; and he rejected them in his elegiac sequence 'In Memoriam': "I think we are not wholly brain, Magnetic mockeries ..."

Notonly cunning casts in clay:

Let Science prove we are, and then

What matters Science unto men,

At least to me? I would not stay.

To be appalled, I'd suggest, is neither unpoetic nor unscientific. Tennyson had absorbed Charles Lyell's Principles of Geolo$g y$, and, elsewhere in the poem, we see how the concept of deep time broadens the perspective of his mourning. It also intensifies the style, so that Leopardi's words come to mind for the pleasurably swift alternation of images, for the seemingly effortless manner in which they link a revolutionary idea to a traditional sentiment. It matters too that the overlay of images dramatizes an objective idea, and that what is remote and different is the fact that the Earth Tennyson invokes here "in tracts of fluent heat began":

There rolls the deep where grew the tree.

Oearth, what changes hast thou seen!

There where the long street roars hath been

The stillness of the central sea.

Maurice Riordan is at 6 Daniels Road, London SE15 3LR, UK. His most recent collection of poems is Floods (Faber \& Faber). 